\title{
TIPOLOGI DAN TATA KELOLA RESOLUSI KONFLIK DITINJAU DARI PERSPEKTIF TEORI SOSIAL KONFLIK
}

\author{
Wiwik Setiyani \\ Universitas Islam Negeri Sunan Ampel Surabaya, Indonesia \\ E-mail: wiwiksetiyani@uinsby.ac.id
}

\begin{abstract}
This article seeks to analyze the typology of management along with conflict resolution in terms of their correlation to the social theory of conflict. Social conflicts can be categorized into a number of types. Based on their types the social conflicts can be divided into two parts, namely vertical conflict and horizontal conflict. The vertical conflict is a conflict that has bottom-up as well as top-tobottom patterns. Conflict management involves every effort to avoid conflicts which are, generally, violently-biased disputes. Such efforts are founded on the basis of resolution processes employing any means of power and authority. The conflict management implies the existence of conflict interventions carried out by conflicting parties or third parties who have considerable power or resources to stabilize the conflict. Within the context of power, the conflict management is usually implemented in three forms, namely formal-legal power, traditional power, and charismatic power. The formal-legal power is power based on such legitimacy tools as law and legislation. The traditional power is power based on claim of belief, faith, and customs. The charismatic power is power based on personal abilities which deal with magical and supernatural realms.
\end{abstract}

Keywords: Conflict resolution; the social theory of conflict.

\section{Pendahuluan}

Pada tahun 1992, kalangan intelektual dan pengamat sosial-politik dunia diguncangkan oleh terbitnya buku berjudul, The End of History and the Last Man, buku ini ditulis oleh seorang pemikir terkemuka 
Amerika Serikat, Francis Fukuyama (1952). ${ }^{1}$ Dalam bukunya tersebut, Fukuyama mengemukakan bahwa pascaperang dingin II yang diakhiri oleh kekalahan Uni Soviet dari Amerika Serikat dan sekutunya, peradaban dunia tidak akan lagi dibenturkan oleh tarikan dua kutub ideologi ekstrim dunia, antara kapitalisme dan sosialisme. Menurutnya, kemenangan Amerika Serikat dan nega-negara sekutu merupakan titik pamungkas sejarah evolusi sosial-budaya umat manusia, dan bersamaan dengan itu negara-negara dunia akan dihadapkan pada satu tatanan kehidupan baru, yaitu tatanan demokrasi liberal barat yang dalam pandangan Fukuyama diklaim sebagai sistem pemerintahan dunia paling akhir. Fukuyama meyakini, sistem demokrasi liberal barat akan menjadi sistem pemerintahan tunggal yang akan membuat negara-negara dunia menjadi universal dan homogen, sehingga tidak akan ada satu pun sistem alternatif yang dapat menggantikannya. ${ }^{2}$

Selang beberapa tahun setelah kemunculan tesis Fukyama tentang The End of History, kalangan intelektual dan pengamat politik dunia kembali dibuat gempar oleh kemunculan buku Samuel Huntington (1927-2008). Pada tahun 1996, Huntington menerbitkan buku kontroversial, berjudul The Clash of Civilizations and the Remaking of World Order. ${ }^{3}$ Pada mulanya buku ini merupakan bantahan Huntington terhadap tesis muridnya, Francis Fukuyama, yang menyatakan bahwa kebaradaan dunia di era pascaperang dingin sebagai akhir dari sejarah. Menurut Huntington, kondisi dunia pascaperang dingin adalah satu babak baru munculnya benturan-benturan dunia. Jika pada mulanya faktor terjadinya konflik dan benturan dunia lebih didominasi oleh dua kepentingan sistem ideologi besar, antara kapitalisme Amerika Serikat dan sosialisme Uni Soviet, maka pada era pascaperang dingin, konflik dan benturan negara-negara dunia akan lebih banyak disebabkan oleh unsur budaya dan agama. ${ }^{4}$ Bahwa pada masa-masa ke depannya, agama dan budaya akan menjadi faktor dominan terjadinya segala bentuk kekacauan antarnegara-negara dunia. Khususnya di

\footnotetext{
1 Mohamad Rosyidin, "Konflik Internasional Abad ke-21? Benturan Antarnegara Demokrasi dan Masa Depan Politik Dunia", Jurnal Ilmu Sosial dan Ilmu Politik, Vol. 18, No. 3 (2015), 224.

2 Alex Sobur, "Membangun Dialog Antarperadaban", Mimbar: Jurnal Sosial dan Pembangunan, Vol. 18, No. 2 (Juni 2002), 123.

3 Samuel P. Huntington, The Clash of Civilization? (Summer: Foreign Affairs, 1993), 34-35.

4 Vita Fitria, "Konflik Peradaban Samuel P. Huntington; Kebangkitan Islam yang Dirisaukan?”, Humanika, Vol. 9, No. 1 (Maret 2009), 44.
} 
negara-negara tertentu yang memiliki sistem peradaban cukup berlainan dengan sistem budaya dan agama barat sekuler, seperti halnya peradaban timur. Untuk memperkuat tesisnya, Huntington membagi peradaban dunia ke dalam tujuh peradaban major, yaitu: Tionghoa, Jepang, Hindu, Islam, Rusia (Kristen Ortodoks), Barat, dan Amerika Latin. ${ }^{5}$

Atas pembacaannya ini, pemikiran Huntington pun menuai prokontran dari banyak kalangan. Tidak sedikit menilai bahwa teori "benturan peradaban" yang dikemukakan Huntington akan memicu lahirnya ketegangan di kalangan negara-negara dunia, dan membuat hubungan antarnegara-negara dunia menjadi merenggang. Khususnya negera-negara di luar barat yang notabeni memiliki sistem peradaban, budaya, dan agama berbeda dengan barat sendiri, seperti halnya negara-negara Timur Tengah, Afrika, dan sebagainya. Namun tidak sedikit juga yang menyambut hangat dan menyetujuinya. Mereka beranggapan teori benturan peradaban yang dilontarkan Samuel Huntington sebagai buah pemikiran monumental yang dapat memberi sumbangsih besar bagi perkembangan dan kemajuan dunia ke depannya.

Pada perkembangan selanjutnya, perbincangan teori benturan peradaban dari seorang Huntington menemukan puncaknya, tepatnya ketika terjadi peristiwa penyerangan terhadap dua simbol ekonomi dan militer Amerika Serikat, World Trade Center dan markas Pentagon di Washington DC. ${ }^{6}$ Keruntuhan dua gedung pencakar langit tersebut seolah menjadi titik pembenar, bahwa dalam beberapa tahun ke depan dunia akan dipenuhi berbagai konflik sosial lintas peradaban yang bermuara dari dimensi agama dan kebudayaan. Benar saja, pascateror gedung pencakar langit ala kamikaze Jepang di atas, dalam waktu relatif singkat tuduhan langsung diarahkan kepada kelompok Islam, yakni sosok Usamah Bin Laden sebagai aktor intelektual di baliknya. Pada akhirnya, disebutnya nama Usamah, dan kelompok islam secara umum, sebagai dalang aksi teror 11 September 2001, secara langsung menyeret Islam ke dalam konfrontasi dan konflik peradaban. ${ }^{7}$ Muncul banyak sentimen anti-Islam dan anti-Muslim di belahan dunia, khususnya Amerika Serikat. Tempat-tempat ibadah seperti Masjid dan

\footnotetext{
${ }^{5}$ Samuel P. Huntington, Benturan Antarperadaban dan Masa Depan Politik Dunia, terj. M. Sadat Ismail (Yogyakarta: Qalam, 2002), 47-49.

${ }^{6}$ Azyumardi Azra, Konflik Baru Antar Peradaban (Jakarta: RajaGrafindo, 2002), 9.

${ }^{7}$ Huntington, Benturan Antarperadaban, 51.
} 
Islamic center di belahan dunia menjadi sasaran kemarahan masyarakat non-Muslim. Pada tahap ini, apa yang disebut Huntington sebagai teori benturan peradaban, bahwa konflik negara-negara dunia akan meledak karena disulut oleh unsur agama dan kebudayaan, perlahan namun nyata menemukan ruang kebenarannya. ${ }^{8}$

Pada level teoretis, mengemukanya teori benturan peradaban Huntington di kalangan intelektual dan pemikir sosial, pada perkembangannya mengundang perhatian dan kesadaran banyak pihak untuk menampilkan satu paradigma berpikir yang berorientasi pada pembangunan perdamaian negara-negara dunia. Dalam kaitan ini, banyak kalangan sepakat bahwa cara paling mungkin untuk mencegah tergadinya konflik antarperadaban adalah dengan mengupayakan dialog antarperadaban.' Hanya, semakin derasnya globaliasi dan kompleksnya persoalan stabilitas transnasional, sedikit banyak membuat upaya jalan dialogis tersendat. Konsekuensinya, dalam beberapa dekade terakhir muncul kecenderungan atas semakin meningkatnya eskalasi konflik di tataran kehidupan masyarakat. Menariknya, konflik sosial bukan lagi terjadi dalam lingkup antaragama dan kebudayaan, seperti yang diperediksikan Huntington, melainkan terjadi dalam wilayah sekte dan kelompok keagamaan sendiri. ${ }^{10}$ Bahwa ketegangan dan polarisasi sosial telah megalami pergerseran, di mana pada masa kontemporer ini telah terjadi semacam sintemen kesukuan dan kesektean yang mengakibatkan benturan di tataran wilayah internal keagamaan. Bukan lagi dengan wilayah keyakinan yang berada di luar dirinya.

Semakin bervariannya realitas konflik sosial di tataran kehidupan masyarakat, pada akhirnya mengantarkan banyak kalangan pada satu proposisi, bahwa konflik sosial yang telah bergulir panjang dalam sejarah kehidupan masyarakat, pada hakikatnya merupakan fakta sosial yang tidak akan terbantahkan. ${ }^{11}$ Konflik akan senantiasa ada bersamaan dengan bergulirnya sejarah keberadaan manusia itu sendiri. Merujuk pada tesis besar sosiolog Karl Marx, konflik adalah bukti nyata atas keberlangsungan hidupan manusia yang muncul seiring proses dialektika kelas sosial manusia, antara kelas sosial tinggi

\footnotetext{
${ }^{8}$ Ibid., 653.

9 Azra, Konflik Baru AntarPeradaban, 8.

${ }^{10}$ John L. Esposito, Masa Depan Islam, terj. Eva Y. Nukman dan Edi Wahyu SM (Bandung: Mizan, 2010), 33.

${ }_{11}$ Novri Susan, Sosiologi Konflik dan Isu-isu Konflik Kontemporer (Jakarta: Prenada Media Group, 2009), 4.
} 
(borjuis) dan kelas sosial rendah (proletar). ${ }^{12}$ Sejarah kehidupan manusia adalah sejarah pertentangan kelas sosial, yang dalam pandangan Ali Syariati, hal itu diklaim telah ada semenjak awal mula lahirnya peradaban manusia di muka bumi. Sejarah pertentangan Qobil dan Habil pada masa kenabian Adam yang berujung pada kematian salah satunya, menurut Ali Syari'ati (1933-1977) adalah bukti nyata bahwa konflik adalah bagian dari sejarah kehidupan manusia yang akan selalu ada dari waktu ke waktu. ${ }^{13}$

Dalam perkembangan berikutnya, seiring timbulnya kesadaran para pemikir dan pemerhati studi konflik sosial dunia, diskursus tentang konflik akhirnya mengkerucut pada upaya lebih intens dan terfokus, yakni bagaimana memunculkan sebuah diskursus konflik yang bertul-betul fokus membahas dinamika konflik dalam perspektif keilmuan tertentu. Salah satu yang berkembang adalah studi tentang tata kelola atau manajemen konflik kontemporer, dengan melandaskan pembacaan pada teori-teori konflik sosial. Jika ditelusuri lebih jauh, diskursus ilmiah tentang konflik sejatinya telah lama bergulir, bahkan mendahului teori konflik benturan peradaban Huntington. Ada banyak tokoh intelektual sosial yang tergabung dalam proyek ini. Baik mereka yang datang dari latar intelektual modern maupun yang berlatar klasik. Beberapa di antaranya adalah Karl Marx (1818-1883), Ralf Dahrendorf (1929-2009), Lewis A. Coser (1975-2003), Ibn Khaldun (1332-1402), dan sebagainya. Berkenaan dengan studi ini, secara umum artikel ini memiliki kepentingan akademik untuk menelusuri, menggali, dan mendeskripsikan keseluruhan konsep konflik di atas, yang meliputi teori-teori konflik, tipologi konflik, serta tata kelolanya, sehingga ke depannya diharapkan dapat menawarkan satu bangunan studi konflik sosial yang betul-betul komprehensif dan juga utuh.

\section{Anatomi Konflik Berdasarkan Tipe dan Jenisnya}

Pada tataran teoretis, sebagaimana telah dipaparkan di muka, konflik dapat disederhanakan sebagai situasi pertentangan kepentingan yang ditandai oleh pergerakan dari beberapa pihak sehingga menyebabkan persinggungan. ${ }^{14}$ Konflik terjadi dalam motif

12 Zainuddin Maliki, Narasi Agung: Tiga Teori Sosial Hegemonike (Surabaya: LPAM, 2003), 163.

13 M. Ramadhan, "Teologi Kemanusiaan Studi Atas Pemikiran Ali Syariati", TEOLOGLA, Vol. 22, No. 2 (Juli 2011), 3.

14 Susan, Sosiologi Konflik, 5. 
dan bentuk yang beragam, dapat berupa antarindividu dan individu lain, antarindividu dengan kelompok, antarkelompok dan kelompok, antarkelompok dengan negara, dan antarnegara dengan negara. Persisnya, konflik memuat sifat dan motif yang kompleks, setiap bentuk konflik mempunyai pendekatan dan arah perkembangan masing-masing. Karena sifatnya yang kompleks itulah, upaya tata kelola konflik membutuhkan pendekatan dan strategi khusus. Salah satunya adalah dengan melakukan pengelompokan konflik berdasarkan jenis dan tipenya.

Berdasarkan jenisnya, konflik dapat dipetakan pada dua bagian, yakni konflik vertikal dan konflik horizontal. Vertikal berarti tegak lurus dari bawah ke atas atau kebalikannya, jika disandarkan pada arti suku katanya tersebut, konflik vertikal berarti jenis konflik yang berpola dari atas ke bawah, atau sebaliknya dari bawah ke atas. Adapun secara teroritis, sebagaimana dijelaskan oleh Novri Susan (2009), konflik vertikal adalah satu karakteristik konflik yang melibatkan kaum elit dan rakyat atau massa. ${ }^{15}$ Konteks makna elit di sini dapat berupa beragam kelas sosial, bisa berupa aparatur pemerintah, bisa kaum pemodal (baca: kapital), dan bisa juga berupa tokoh bangsawan. Persisnya, elit adalah setiap mereka yang secara status sosial memiliki kedudukan hierarki atas, yang kesemuanya didasarkan pada bangunan struktur dan sistem sosial yang bersifat kearifan lokal. Di Madura, misalnya, konteks makna status sosial tidak saja ditujukan kepada aparatur pemerintah, namun juga berlaku pada tiga elit lokal; kiai, blater, dan kalebun. Jika term elit memuat makna kelas sosial atas, maka sebaliknya term rakyat dalam konflik vertikal merujuk pada masyarakat kelas sosial menengah ke bawah. Dalam konteks negara-bangsa, elit diwakili oleh aparatur pemerintah, sedangkan kelas sosial bawah adalah rakyat. Dalam dunia industrial, elit adalah mereka pemegang modal, sedangkan kelas bawah adalah para buruh dan pekerja. Sirkulasi kepemimpinan, elit adalah mereka para pemimpin, politisi, dan pemangku kepentingan politis, sedangkan masyarakat bawah adalah kalangan voter di akar rumput.

Secara teoretis, konflik vertikal yang melibatkan hierarki kelas atas dan hierarki kelas bawah, pada umumnya terjadi karena faktor kekuasaan. ${ }^{16}$ Hal demikian disebabkan oleh karakter kuasaan, di mana dalam batasan-batasan tertentu, kekuasaan mempunyai sifat

\footnotetext{
${ }^{15}$ Ibid., 92.

${ }^{16}$ KBBI online, https://kbbi.web.id/, diakses pada 05 Februari 2016.
} 
hegemonik dan eksploitatif. Sifat kekuasaan yang hegemonik seringkali menjadi instrument untuk menaklukkan sistem dan struktur sosial di bawahnya. Begitupun juga seterusnya, sifat eksploitatif kekuasaan memicu lahirnya praktik-praktik ketidakadilan, di mana pemegang kekuasaan seringkali memanfaatkan masyarakat kelas bawah untuk memenuhi kepentingan ekonomis dan politisnya. Dalam praktiknya, sifat hegemonik kekuasaan dapat dilihat dari hubungan negara dengan rakyatnya. Negara seringkali menggunakan cara-cara kekerasan dan kekuatan militer untuk menertibkan dan mengkondisikan masyarakat. Adapun sifat eksploitatif kekuasaan tergambar jelas dalam hubungan majikan atau pemegang modal dengan para pekerja atau buruh. Buruh sebagai pekerja senantiasa diperlakukan tidak adil, upah yang sedikit, tidak adanya jaminan kesehatan, dan rendahnya taraf kesejahteraan hidup. Dalam pemaknaan sederhana, konflik vertikal dipicu oleh adanya dua hal, yakni praktik-praktik kekuasaan yang cenderung hegemonik dan eksploitatif, serta dominasi kelas sosial kelompok superordinatif terhadap kelompok subordinatif.

Sedangkan horizontal berarti garis bidang yang sejajar atau garis datar. Dengan demikian, konflik horizontal adalah jenis konflik yang mempunyai pola datar dan bersifat sejajar. Pola ini sangat kontradiktif dengan konflik vertikal, jika vertikal merujuk pada pertentangan kelas sosial yang bersifat hierarki, maka konflik horizontal lebih kepada konflik tanpa melibatkan kelas sosial tertentu. Secara teoretis, Novri Susan (2009) mengartikan konflik horizontal sebagai konflik yang bergulir di kalangan massa sendiri. ${ }^{17}$ Konflik massa pada umumnya terjadi karena faktor-faktor sosial yang berhimpitan langsung dengan kehidupan sehari-hari. Unsur-unsur yang berkenaan dengan agama, kebudayaan, tradisi, etnisitas, dan sumber-sumber ekonomi, kesemua elemen tersebut seringkali menjadi faktor dominan terjadinya konflik horizontal. Mengacu pada penjelasan ini, maka dapat dipastikan pola kerja konflik horzinotal jauh berlainan dengan konflik vertikal. Tidak ada intervensi kelas sosial atau praktik kekuasaan tertentu, karena konflik ini lebih banyak dipengaruhi isu-isus sosial kemasyarakatan, bukan oleh struktur-struktur kekuasaan kelas sosial tertentu seperti konflik sosial vertikal pada umumnya.

Dari semua penyebab konflik horizontal di atas, unsur agama dan kesukuan adalah dua faktor dominan yang dengan mudah dapat

${ }^{17}$ Susan, Sosiologi Konflik, 93. 
menyulut terjadinya pertentangan di kalangan masyarakat. Pertanyaan besarnya adalah, kenapa agama dan unsur etnisitas-kesukuan menjadi faktor dominan pemicu terjadinya konflik horizontal? Pertama, agama dalam kenyataannya dipahami sebagai realitas suci, baik dalam kapasitasnya sebagai ajaran dalam berpikir maupun sebagai pedoman hidup dalam bersikap dan bertindak. Bagi setiap penganutnya, agama diyakini sebagai sumber moral tertinggi, menyimpan kesucian dan keagungan yang berlandaskan langsung pada wakyu tuhan dan ajaran para rasul. Sifat agama yang suci dan agung tersebut, pada gilirannya melahirkan sikap dan perilaku penghormatan totalitas, fanatisme, bahkan pengkultusan dari para pemeluknya. Fanatisme dan pengkultusan terhadap simbol keagamaan tertentu, pada gilirannya memunculkan sikap eksklusivisme. ${ }^{18}$ Yaitu kecenderungan untuk melihat keyakinan pribadi sebagai satu-satunya kebenaran, dan pada saat bersamaan melihat keagamaan lain di luar dirinya sebagai bentuk penyimpangan dan kesesatan. Kenyataan inilah yang kemudian menjadi sebab mengapa agama dengan mudah dapat memicu konflik, terutama ketika mengalami persinggungan dengan paham keagamaan di luar dirinya. Di beberapa daerah yang terkenal memegang teguh simbol dan lambang keagamaan, seperti halnya di kalangan masyarakat Madura yang dikenal sangat menjunjung tinggi simbolsimbol agama (baca: religiositas), ${ }^{19}$ isu-isu agama lebih mudah menyulut konflik daripada isu sosial lain di luarnya, isu ekonomi dan politik, misal. Kedua, kenyataan bahwa etnisitas dan kesukuan selalu dhadapkan pada streotipe tertentu. Di banyak negara, termasuk sebagian besar daerah Indonesia, salah satu persoalan krusial menyangkut entnisitas dan kesukuan adalah masih mengentalnya pandangan strotipe terhadap keberadaan suku atau ras tertentu. Jika belajar pada sekian kasus konflik horizontal terdahulu, fakta menunjukkan mayoritas konflik lintas suku dan ras di kalangan masyarakat terjadi karena dipicu oleh isu-isu sosial yang menyangkut persoalan identitas. Dalam kaitan ini, seringkali muncul kecenderungan suku atau ras tertentu menaruh pandangan negatif (streotipe) terhadap golongan masyarakat yang secara geografis dan kebudayaan berbeda dengan mereka. Pada kondisi tertentu, konflik

18 Abd Hannan, "Fanatisme dan Stigma Sosial Pesantren Miftahul Ulum terhadap Kelompok Muhammadiyah di Pamekasan” (Tesis--Universitas Airlangga, 2016), 169.

19 Abd Hannan, Perempuan Madura, Gender, dan Pembangunan (Yogyakarta: Pusat Kajian Sosiologi UTM bekerja sama dengan Penerbit Elmatera, 2016), 23. 
horizontal yang disebabkan oleh unsur kesukuan dan etnisitas akan menjadi sulit dikendalikan ketika dibumbui oleh isu-isu sosial lain yang lebih fundamental, seperti isu ekonomi, kedaulatan, dan penguasaan sumber alat produksi ekonomi lokal.

Selain berdasarkan jenisnya, konflik sosial dapat juga dikelompokkan berdasarkan tipenya. Dari suduh pandang ini, Novri Susan (2009) membagi konflik pada empat bagian, yakni konflik tanpa pertentangan fisik, konflik laten, konflik, terbuka, konflik di permukaan. ${ }^{20}$ Konflik sosial tanpa pertentangan fisik mengandaikan pada situasi sosial di mana tidak didapati adanya kekacauan dan disintegrasi sosial di tataran masyarakat. Sebaliknya, pada situsi ini konflik lebih dipenuhi oleh keberadaan dan hubungan kelompok sosial yang saling memenuhi dan saling mengisi. Secara sosiologis, demikian terjadi karena dipengaruhi oleh kemampuan masyarakat menciptkan satu sistem dan struktur sosial yang dapat menghindarkan mereka dari sikap, perilaku dan tindakan sosial yang mengandung unsur kekerasan. Jika dikaitkan dengan tipe konflik laten, situasi ini sesungguhnya memiliki keserupaan. Hanya, jika konflik tanpa kekerasan fisik meniscayakan pada sterilnya perselisihan dan pertentangan di dalam kelompok, maka lain halnya dengan tipe konflik laten. Secara pengamatan, konflik laten memang menampilkan ketiadaan konflik, namun di balik itu semua terdapat setumpuk persoalan yang berdiam sembunyi di baliknya. ${ }^{21}$ Karena keberadaannya yang terselubung ini, tipe konflik laten menjadi lebih sulit ditangani dan diselesaikan. Cara satu-satunya untuk dapat menyelesaikan adalah dengan menelusuri konflik tersebut hingga ke akar-akarnya, kemudian mengangkatnya ke permukaan sehingga keberadaannya dapat dijangkau secara menyeluruh. Pada umumnya, konflik laten terjadi karena ketiadaan transparansi dalam kelompok. Di Indonesia, konflik laten pernah terjadi di tengah berlakunya sistem pemerintahan orba di bawah kepemimpinan Soeharto. Pada masa ini, konflik laten ditandai oleh kondisi sosial masyarakat yang tampak terlihat stabil dan kondusif. Pada kenyataannya, di balik semua itu tersimpan banyak konflik laten yang mencerminkan kekecewaan dan pertentangan masyarakat.

\footnotetext{
${ }^{20}$ Susan, Sosiologi Konflik, 93.

21 Fisher, dkk, Mengelola Konflik Keterampilan dan Strategi untuk Bertindak, terj. Kartikasari, dkk (SMK Jakarta: Grafika Desa Putra, 2001), 23.
} 
Berbeda dengan tipe konflik laten yang cenderung menyembunyikan persoalan, yaitu konflik bertipekan terbuka. Konflik dengan tipe terbuka adalah situasi tertentu di mana setiap pertentangan dan perselisihan tampil ke luar permukaan dalam bentuk dan wujud yang sangat jelas dan nyata. ${ }^{22}$ Pada situasi tertentu, konflik terbuka memiliki potensi menimbulkan permasalahan lanjutan yang lebih besar dan kompleks, dengan cara sengaja melibatkan individu atau kelompok masyarakat di luarnya, atau dapat pula karena menular ke struktur lain dengan sendirinya. ${ }^{23}$ Untuk itu, konflik pada wilayah ini harus diikuti oleh berbagai upaya penanganan sedini dan dan secepat mungkin. Hal tersebut urgen dilakukan dalam upaya mengatasi akar penyebab dan kemunculan persoalan seoptimal dan semaksimal mungkin. Di Indonesia konflik terbuka seringkali muncul di banyak daerah, bahkan dalam beberapa kesempatan keberadannya sampai menular luas ke berbagai sektor. Hal tersebut terjadi disebabkan oleh kurangnya kesigapan pemerintahan untuk merespondnya.

Selain konflik tipe laten dan konflik tipe terbuka, terakhir adalah konflik di permukaan. Konflik tipe ini adalah wujud pertentangan sosial yang kemuculannya berakar dari satu persoalan yang bersifat dangkal, atau dalam bahasa yang lain dapat juga dikatakan sebagai konflik yang bersumber dari problem sosial kecil dan sederhana. ${ }^{24}$ Hanya, berhubung konflik ini seringkali dibumbui oleh unsur lain berupa kesalahpahaman dan sejenisnya, maka dalam prosesnya konflik ini tetap bergulir ke permukaan. Karenanya, untuk dapat menangkal gejolak konflik ini berubah membesar dan meluas, diperlukan upaya mediasi sekiranya dapat menjelaskan titik kesalahpahaman tersebut, mendudukkan titik permasalahan yang sesungguhnya sehingga akar persoalannya menjadi jelas dan sesuai. Dalam kejadiannya, paling dominan konflik di permukaan banyak terjadi di kalangan anak muda dan remaja, misalnya adalah tawuran dan perkelahian antarremaja, tawuran di sekolah, tawuran di jalanan, dan lain sejenisnya.

22 St. Aisyah BM, "Konflik Sosial Dalam Hubungan Antar Umat Beragama”, Jurnal Dakwah Tabligh, Vol. 15, No. 2 (Desember 2014), 195.

${ }^{23}$ Simon Fisher, dkk, Mengelola Konflik: Keterampilan dan Strategi Untuk Bertindak, terj. S. N. Kartikasari, dkk (Jakarta: The British Counsil Indonesia, 2001), 13.

${ }^{24}$ Irwandi, Endah R. Chotim, "Analisis Konflik Antara Masyarakat, Pemerintah dan Swasta; Studi Kasus di Dusun Sungai Samak, Desa Sungai Samak, Kecamatan Badau, Kabupaten Belitung", JISPO, Vol. 7, No. 2 (2016), 28. 


\section{Teori Sosial Konflik Lintas Paradigma}

Sebelum lebih jauh membahas teori sosial konflik secara mendalam, terlebih dahulu akan dijelaskan pengertian paradigma itu sendiri. Hal ini penting untuk memberi pemahaman komprehensif, serta menjawab beberapa persoalan terkait pentingnya memahami konsep paradigma sebagai bagian penting dalam diksursus dan tata kelola konflik.

Menurut Thomas Kuhn dalam buku The Structure of Scientific Revolution, memahami paradigma sebagai cara mengetahui realitas sosial yang dikonstruksi oleh mode of thought atau mode of inquiry tertentu, yang kemudian menghasilkan mode of knowing yang spesifik. Sedangkan menurut George Ritzer (2004), paradigma adalah pandangan mendasar tentang apa yang menjadi pokok persoalan yang semestinya dipelajari. ${ }^{25}$ Paradigma berperan sebagai suatu jendela untuk mengamati permasalahan konflik, dari mana ia dapat memahami dan menafsirkan secara objektif konsep-konsep, asumsiasumsi, dan kategori-kategori tertentu. Jika mendasarkan pada dua pengertian tokoh di atas, paradigma dapat dipahami sebagai bagian fundamental yang berfungsi strategis melakukan pemetaan masalahmasalah sosial secara lebih terarah. Dalam pemahaman lainnya, paradigma dapat pula dimengerti sebagai basic berpikir yang dapat menentukan arah penggunaan suatu teori dan metodologis. Dalam kedudukannya ini, dapat dikatakan kesalahan memahami penggunaan paradigma akan berefek pada kesalahan dalam berteori. Begitupun seterusnya, kesalahan berteori akan berpengaruh besar terhadap aspek metodologis. Dengan demikian, antara paradigma, teori, dan metodologi, kaitannya dengan pembahasan teori sosial konflik, adalah satu perangkat ilmiah yang bersifat terstruktur dan sistematis.

Poin penting yang perlu digarisbawahi, berkenaan dengan pembahasan pradigma adalah kenyataan bahwa sifat paradigma yang tidak tunggal. Menurut Rtizer (2004), paradigma memiliki sifat ganda, demikian disebabkan oleh fungsi paradigma dalam kapasitasnya sebagai landasan berpikir untuk mengamati dan menganalisa permasalahan-permasalahan sosial, termasuk di dalamnya menyangkut

25 George Ritzer, Sosiologi Ilmu Pengetahuan Berparadigma Ganda, terj. Alimandan (Jakarta: PT Raja Grafindo Persada, 2004), 9. 
permasalahan konflik. ${ }^{26}$ Selain itu, kenyataan bahwa konflik memiliki kompleksitas, baik dalam hal faktor penyebab, konteks sosialnya, dan arah perkembangannya, membuat keberadaannya menjadi sulit dipahami dan dipecahkan jika sekadar mengandalkan satu paradigma. Karenanya, berkenaan dengan paradigma teori sosial konflik ini, sekurang-kurangnya terdapat tiga paradigma sosial yang umumnya digunakan banyak ilmuan sosial untuk menganalisa permasalahanpermasalahan dalam konflik, yakni paradigma positivistik, paradigma humanis, dan paradigma kritis. Penjelasan ketiganya akan disampaikan dalam sub bab pembahasan tersendiri.

Adapun teori secara konseptual dipahami sebagai suatu pernyataan yang telah terbukti kebenarannya. Teori dapat pula dipahami sebagai pendapat yang dikemukakan untuk keterangan mengenai suatu peristiwa, kejadian, dan sebagainya. ${ }^{27}$ Teori berakar dari pembacaan komprehensif, di mana dalam prosesnya melibatkan tahap-tahap tertentu yang sistematis dan berstruktur. Sebelum dimunculkan sebagai asas dan hukum pengukur kebanaran, teori muncul melalui tahap pengamatan dan pengujian yang terukur, dan itu dijalankan melalui langkah-langkah normatif yang sifatnya metodologis. Karena proses yang kaku tersebut, teori memiliki kelebihan dan keunggulan sebagai alat analisis dan pengkajian, atau sebagai rangkaian instrument untuk membaca gejala-gejala sosial di tengah masyarakat, atau bahkan hingga menyangkut persoalan sekalipun, sehingga dimungkinkan untuk dapat memperoleh jawaban dan jalan keluar.

Secara genealogis, diskusus teori dan paradigma sosial konflik sejatinya sudah berlangsung dalam rentang waktu cukup lama. Mulai dari masa klasik di bawah pengaruh Ibn Khaldun hingga era postmodern di bawah pemikiran besar Jurgen Habermas, Michel Foucault, dan sebagainya. Ada banyak pemikir dan tokoh intelektual yang diketahui sebagai pakar di bidangnya. Beberapa di antara mereka ada yang berlatar sebagai pakar teori konflik di era klasik. ${ }^{28}$ Mereka yang tergabung dalam aliran ini di antaranya adalah, Karl Marx, Ibn Khaldun, Emile Durkheim, dan Max Weber. Beberapa lainnya disebut sebagai tokoh pemikir sosial konflik era modern, yang kemudian

\footnotetext{
${ }^{26}$ Ibid., 9.

${ }^{27}$ KBBI online, https://kbbi.web.id/, diakses pada 05 Februari 2016.

${ }^{28}$ Douglass J. Goodman dan Ritzer, Teori Sosiologi Dari Klasik Sampai Postmodern, terj. Nurhadi (Bantul: Kreasi Wacana, 2010), 1.
} 
disebuat sebagai teori konflik modern. Nama-nama teoretisi sosial seperti Talcot Parson, Lewis A. Coser, Robert K. Merton, dan Ralf Dahrendorf, kesemunya adalah deretan pemikir konflik yang masuk di era ini. ${ }^{29}$ Dan dalam babakan sejarah berikutnya, berkembang teoriteori konflik lebih kekinian, yang dikenal dengan era postmodern. Pada tahap ini, kebanyakan pemerhati konflik meyebut produk pemikiran konflik di era ini sebagai teori konflik kritis. ${ }^{30}$ Tokoh-tokoh yang masuk dalam kelompok ini adalah Jurgen Hebermas, Michel Foucault, dan sebagainya. Untuk lebih jelasnya, berikut akan dijelaskan masing-masing pemikiran konflik di atas berdasarkan babakan periode, paradigma, dan sejarahnya.

\section{Teori Konflik Paradigma Positivistik}

Paradigma positivistik atau positif, adalah satu paradigma keilmuan sosial yang sangat menekankan pada metode-metode statistical ilmu alam. Hal ini tidak lepas dari bangunan dasar filosofisnya yang bertumpu pada pemikiran filsafat Aguste Comte, yang dikenal sebagai bapak filsafat positivism dunia. ${ }^{31}$ Terdapat tiga asumsi dasar tentang paradigma ini; pertama, paradigma ini beranggapan bahwa perilaku masyarakat memiliki keterkaitan erat dengan bangunan sistem dan struktur sosial yang ada di lingkungannya. Dengan artian, setiap tindakan individu ataupun kelompok pada hakikatnya merupakan wujud kausalitas dari lingkungannya. Berkenaan dengan kajian ini, konflik sosial dapat dipahami sebagai bentuk dari keterpaksaan individu atau masyarakat dari sistem dan struktur sosial yang mengikat dirinya. Kedua, paradigma positivistik mendudukkan masyarakat sebagai realitas sosial yan terdiri dari berbagai struktur dan kelompok tertentu. Setiap struktur memiliki peran dan fungsi masing-masing yang saling berhubungan dan saling memengaruhi. Konsep hubungan di sini bisa dalam arti saling kerja sama ataupun persaingan, persahabatan ataupun permusuhan. Dalam konteks ini, konflik dapat dimaknai sebagai perwujudan dari salah satunya, bisa dalam wujud persaingan, persahabatan, permusuhan, ataupun kerjasama. Ketiga, sebagai realitas berbentuk struktur, paradigma positivism memercayai masyarakat akan senantiasa bergerak berubah, baik proses perubahan tersebut

\footnotetext{
${ }^{29}$ Goodman dan Ritzer, Teori Sosiologi, 205.

${ }^{30}$ Ibid., 645.

31 Sunyoto Usman, Sosiologi, Sejarah, dan Metodologi (Yogyakarta: CiRed, 2004), 3.
} 
terjadi dalam gerak lamban (evolusi) maupun gerak cepat (revolusi). Dalam kaitan ini, konflik dianggap sebagai bagian dinamika perubahan, yang dalam batasan-batasan tertentu dinilai akan menghadirkan dampak positif bagi perkembangan dan perubahan masyarakat. ${ }^{32}$

Secara garis besar, teori sosial konflik berparadigma positivitik dapat dipetakan ke dalam tiga pemikiran besar, yakni pemikiran konflik Karl Marx, Ralf Dahrendorf, dan Lewis Coser. Dalam diskursus ilmu sosial, ketiganya digolongkan sebagai teoretisi penganut aliran struktural, sehingga kebanyakan pemerhati konflik sosial menyebut produk pemikiran mereka sebagai konflik struktural. Teori ini juga memiliki sebutan lain, yakni teori konflik makro yang disandarkan pada sasaran pokok kajian sosiologis berupa perilaku dan struktur sosial. ${ }^{33}$ Secara umum, asumsi dasar ketiga teori ini berpangkal dari penolakan mereka terhadap apa yang diyakini oleh penganut struktural fungisonal, terutama pemikiran Talcot Parson, yang menyebutkan bahwa struktur masyarakat terbentuk dan bergerak dalam pola yang seimbang. Ketidakseimbangan struktur masyarakat adalah ancaman yang dapat menimbulkan distabilitas dan disintegrasi sosial. $^{34}$

Berbeda dari struktural fungsional, struktural konflik lebih memilih bersikap kontras. Menurut aliran ini, tesis bahwa ketidakseimbangan sub struktur masyarakat sebagai ancaman terhadapstabilitas sosial tidak dapat dibenarkan. Sebaliknya, mereka berpandangan bahwa setiap gesekan dan persinggungan dalam struktur masyarakat adalah proses dialektika yang dapat melahirkan kebaikan. $^{35}$ Persinggungan adalah satu keniscayaan sebagai konsekuensi logis proses pergerakan struktur masyarakat menuju tahap perubahan lebih kompleks. Baik perubahan tersebut terjadi dalam gerak lamban (evolusi) maupun gerak cepat (revolusi). Karenanya, setiap persinggungan harus dimaknai sebagai arah perkembangan baru yang harus dikelola dan ditata sebaik mungkin. Berkenaan dengan ini, Lewis Coser menegaskan, konflik selain berfungsi sebagai sistem penyeimbang, pun juga berfungsi positif

32 Donny Gahral Adian, Percik Pemikiran Kontemporer (Yogyakarta: Jalasutra, 2002), 27.

33 Usman, Sosiologi, 61.

${ }^{34}$ Sindung Haryanto, Spectrum Pemikiran Sosial (Yogyakarta: Ar-Ruzz Media, 2011), 11.

35 Ibid., 40. 
terhadap masyarakat melalui perubahan-perubahan sosial yang ditimbulkannya. ${ }^{36}$

Perlu digarisbawahi, meski asumsi konflik paradigma postivistik memiliki kesamaan pandangan dalam melihat konsep masyarakat, namun dalam beberapa hal terdapat aspek pembeda, terutama menyangkut faktor pemicu lahirnya konflik itu sendiri. Dalam konteks ini, ada jarak pemisah antara Karl Marx dan Ralf Dahrendorf, ketika keduanya menawarkan konsep konflik beserta sumber pemicunya. Menurut Karl Marx, konflik ditandai oleh pertentang kelas sosial atas (borjuis) dan kelas sosial bawah (proletar), di mana motif pertentangan terebut dipicu oleh faktor utama berupa materi. ${ }^{37}$ Persisnya, penguasaan kaum pemodal terhadap sumber dan alat produksi ekonomi berakibat pada hubungan kelas sosial yang tidak seimbang, sehingga pada akhirnya berujung pada praktik eksploitasi dan ketidakadilan. Jika ditelusiri lebih jauh, klaim Karl Marx yang menyebut materi sebagai sumber utama konflik, adalah cerminan dari konstruksi filosofisnya dirinya, yaitu materialism dialektik, bahwa materi (baca: ekonomi) beserta sumber-sumbernya merupakan pondasi utama kehidupan.

Berbeda dengan Karl Marx yang lebih menitikberatkan pada materi, Ralf Dahrendorf cenderung melihat konflik sebagai representasi praktik-praktik kekuasaan. ${ }^{38}$ Artinya, jika struktural konlfik Karl Marx bertumpu pada materi atau sumber ekonomi sebagai faktor tunggal, maka struktural konflik Ralf Dahrendorf lebih condong pada unsur kekuasaan sebagai faktor pemicu konflik. Menurut Dahrendorf, masyarakat akan senantiasa berada dalam perubahan yang ditandai oleh adanya pertentangan secara terus menerus dan berkelanjutan. ${ }^{39}$ Pertentangan di sini meuncul sebagai konsekuensi adanya distribudi kekuasaan yang tidak merata, di mana salah satu pihak menempati posisi sebagai kelompok penguasa (superordinasi), dan pihak lainnya menjadi kelompok yang dikuasa (subordinasi). Hubungan hierarki di sini pada gilirannya menempatkan masyarakat berada poisisi berlawanan, di mana setiap dari mereka digerakkan oleh kepentingan pribadi yang bersifat tersembunyi. Karena kenyataan inilah, Dahrendorf menyebut hubungan dua

${ }^{36}$ Ibid., 51.

${ }^{37}$ Adian, Percik Pemikiran Kontemporer, 101.

38 Ralf Dahrendorf, Konflik dan Konflik Dalam Masyarakat Industri; Sebuab Analisa Kritik Ralf Darbrendorf (Jakarta: Rajawali, 1986), 31.

${ }^{39}$ Goodman dan Ritzer, Teori Sosiologi, 26. 
kelompok ini sebagai keterpaksaan yang diproduksi oleh sistem dan struktur kekuasaan. Sehingga setiap individu yang tidak tunduh atau patuh terhadap hal-hal yang menyangkut prinsip-prinsip kekuasaan dan wewenang, maka secara hukum hierarki di benarkan untuk mendapatkan hukuman. Berdasarkan pembacaan inilah, Dahrendorf menyebut hubungan antardua kutub kekuasaan sebagai hububungan yang terkoordinir secara paksa (Paratively Coordinated Associations). ${ }^{40}$

\section{Teori Konflik Paradigma Humanis}

Jika ditinjau dari akar kemunculannya, paradigma humanis dapat digolongkan sebagai antithesis paradigma positivistik. Terdapat beberapa tokoh yang menjadi aktor intelektual kemunculan paradigma ini, satu sosok paling terkemuka adalah Max Weber. Boleh dibilang Weber adalah bapak paradigma humanisme, sumbangsih pemikiran besarnya adalah ketika memperkenalkan konsep verstehen. Bahwa penelusuran hakikat fenomena sosial (konflik) tidak dapat direduksi pada hubungan kausalitas, sebagaimana dianuti kelompok positivism. Namun harus didasarkan pada proses memahami tindakan-tindakan sosial secara mendalam dan menyeluruh, dan kemudian menguraikannya dengan cara menerangkan sebab-sebab tindakan tersebut. Pada gilirannya, paradigma humanisme Weber mengilhami sederet pemikir sosial konflik lainnya, seperti etnometodologi Garfinkel, Interaksonisme simbolik dari Herbert Mead dan Erving Goffman, konstruksi sosial Peter L. Berger, dan Fenomenologi Alfred Scuhtz. Kesemua tokoh tersebut tergabung dalam aliran konflik humanisme yang menekankan dimensi konflik pada subjektivitas individu, khususnya dalam memahami makna dan simbol.

Secara umum, terdapat dua asumsi dasar paradigma konflik humanisme ini; pertama, masyarakat dalam kedudukannya sebagai realitas sosial merupakan representasi pemaknaan individu terhadap setiap sistem dan struktur sosial di lingkungan mereka. ${ }^{41}$ Individu berkedudukan sebagai kedirian kreatif yang senantiasa menafsirkan segala apa yang terbesit dalam indera mereka. Dalam konteks ini, konflik dipahami sebagai persinggungan interpretasi antarindividu yang bermuara dari prasangka, sikap, dan tindakan kontradiktif. Karenanya, analisis konflik tidak dapat dilakukan berdasarkan penelusuran hubungan kausalitas antara sistem-struktur sosial dan

\footnotetext{
${ }^{40}$ Haryanto, Spektrum Pemikiran Sosial, 47.

${ }^{41}$ George Ritzer, Sosiologi Ilmu Berparadigma Ganda, 12.
} 
individu, namun harus berpusat pada penjelasan menyeluruh dari tindakan-tindakan individu yang diperoleh melalui pemahaman subjektifnya. Kedua, realitas masyarakat dipahami sebagai hasil konstruksi kesadaran dan subjektivitas individu. ${ }^{42}$ Dalam kaitan ini, fenomena sosial konflik muncul melalui proses interaktif bersama yang dilandaskan pada pencarian dan penelusuran simbolis, yakni berupa bahasa dan makna.

Dalam hal teori, ada banyak teori konflik yang tergabung dalam paradigma humanis, dua di antaranya tercatat sebagai teori populer yang umum dipakai untuk menganalisa konflik di tataran mikro sosial, yakni teori Interaksonisme simbolik Herbert Mead. Dalam banyak kesempatan, interaksonisme simbolik selalu dikaitkan dengan keberadaan sosok Herbert Mead yang secara filosfis dipengaruhi oleh peemikiran besar Max Weber, vertehen. Pokok pemahaman teori ini berpusat pada aspek realitas sosial berupa tindakan sosial individu. Menurutnya, dalam diri individu terdapat sisi subjektivitas dan kesadaran diri, di mana setiap tindakan dan perilaku individu tumbuh berasal melalui aspek ini. Dalam teorinya, Herbert Mead menyebut sisi subjektivitas di sini sebagai self, self interaction, dan symbolic meaning. ${ }^{43}$ Self adalah unsur kedirian manusia yang selalu aktif menerima stimulus dari lingkungan. Sedangkan self interaction adalah oraganisme diri yang berperan sentral ketika individu berusaha aktif melakukan proses memahami dan mempertimbangkan. Tahap ini ditandai oleh pemaknaan dan pendefinisian individu terhadap diri dan lingkungannya. Sederhanya, self interaction adalah 'alat penyaringan', individu memilih dan memilah antara bersikap atau tidak, bertindak atau diam, dan seterusnya. Adapun hasil akhir dari penyaringan (self interaction) tersebut, baik berupa sikap, perilaku, atau tindakan, kesemunya disebut dengan pucak pemaknaan, atau dalam bahasa lainnya adalah symbolic meaning. Persisnya, tahap symbolic meaning adalah perwujudan interpertasi simbolik, baik berupa makna atau bahasa, setelah melalui proses self dan self interaction. ${ }^{44}$

\section{Teori Konflik Paradigma Kritis}

Berbeda dengan dua paradigma sebelumnya, paradigma kritis dikenal banyak ilmuan sosial sebagai paradigma yang out of the box.

\footnotetext{
${ }^{42}$ Ibid., 12.

${ }^{43}$ Susan, Sosiologi Konflik, 61.

${ }^{44}$ Ibid., 61.
} 
Satu aliran berpikir yang menekankan pada pembacaan mendalam, frontal, dan menolak terhadap setiap logosentris yang ada di permukaan. ${ }^{45}$ Menurut aliran ini, jawaban tentangan hakikat konflik beserta segala dimensi tidak dapat dipahami sebatas melihat, mengamati, dan mengkaji pada apa yang tampak, melaikan harus menyelinap masuk ke dalam. Berani membongkar setiap kenyataankenyataan lain yang berada sembunyi di baliknya. Dalam bahasa Kantian, aliran berpikir kritis adalah cara berpikir untuk mendapati noumina di balik fenomena, menemuka esensi di balik eksistensi. Beberapa tokoh pemikir yang tergabung dalam proyek pemikir kritis ini terdiri dari lintas pemikir postmodern. Khususnya kalangan pemikir dari golongan madzhab Frunkfurt, seperti halnya Jurgen Hebermas, Theoder Adorno, Herbert Marcuse, Marx Khokheimer, dan beberapa pemikir di luarnya seperti Piere Bourdiue, Michel Foucault, dan lain sebagainya.

Dalam hal teori, konflik madzhab kritis pada umumnya berpangkal pada pemikiran Jurgen Hebermas, dalam hal ini gagasan besar Hebermas tentang tindakan komunikatif dan komunikasi instrumental, dikenal sebagai teori konflik kritis populer yang banyak digunakan para pemerhati konflik kritis, terutama sebagai alat analisis untuk mengkaji permasalahan-permasalahan sosial konflik abad ini. ${ }^{46}$ Menurut Hebermas, sangat berisiko jika menghubungkan problem konflik era kontemporer sebatas pada unsur materi, seperti yang diyakini kelompok marxian. Melihat konflik berdasarkan pertentangan kelas dan perebutan komoditas ekonomi merupakan penyederhanaan masalah. Padahal menurutnya, konflik dewasa ini telah mengalami pergeseran cukup jauh dan signifikan. Dari yang awalnya berpusat di tataran kelas sosial dan sumber produksi ekonomi, kini telah bergeser pada ruang-ruang publik beserta diskursus atau wacana yang dibangunnya. Motif kekuasaan sebagai sumber pemicu konflik tidak dapat lagi dimaknai dalam pengertian yang umum, karena telah berubah pada bangunan-bangunan wacana yang sifatnya diskursif, seperti halnya komunikasi. Dalam kaitan ini, Hebermas menegaskan bahwa realitas sosial masyarakat dibentuk oleh kemampuan setiap personal membangun wacana di lingkungannya. Wacana beserta segala dimensianya, seperti halanya teks, bahasa, dan media informasi

\footnotetext{
${ }^{45}$ Listiyono Santoso, dkk, Epistimologi Kiri (Yogyakarta: Ar-Ruzz Media, 2012), 65.

46 Jenny Edkins dan Nick Vaughan Williams, Teori-teori Kritis (Yogyakarta: Pustaka Pelajar, 2009), 248.
} 
diyakini dapat memproduksi dan mereproduksi realitas. Dengan begitu, berdasarkan keranga berpikir inilah maka konflik dapat dimaknai sebagai representasi komunikasi tertentu yang berorientasi penuh pada pemenuhan unsur politis (baca: kekuasaan). Merujuk pada tesis besar Hebermas, pola komunikasi demikian digolongkan olehnya sebagai komunikasi instrumental, yaitu satu bentuk komunikasi yang tidak berorientasi pada kepentingan dan kesepahaman kolektivitas kelompok, melainkan lebih pada pemenuhan tujuan politis personal atau kelompok tertentu saja. ${ }^{47}$

\section{Strategi Tata Kelola Konflik Sosial Berdasarkan Perspektif Teori Konflik Kontemporer}

Dalam banyak kesempatan, tata kelola konflik selalu dipadankan dengan term manajemen konflik. Secara subtansial kedua term ini mempunyai makna dan pengertian relatif sama, yakni sama-sama mengandaikan pada pengelolaan, penataan, dan pengaturan yang bertujuan mereduksi konflik seproduktif mungkin. Pada satu sisi menjauhkan konflik dari segala bentuk kekerasan, dan pada saat bersamaann menciptakan keseiramaan dan keseimbangan. Di beberapa diskursus studi konflik, khususnya di level akademik, penyamaan term tata kelola konflik dan manajemen konflik menuai perdebatan. Beberapa kalangan memilih setuju, dan sebagian lainnya menolak menyamakan kedua term ini. Mereka yang tidak sepaham dengan penyatuan konsep tata kelola konflik dan manajemen konflik adalah Novri Susan. Dalam bukunya berjudul, Sosiologi Konflik dan Isu-Isu Kontemporer (2009), Novri menolak penyeragaman istilah tata kelola konflik dan manajemen konflik, karena dalam praktiknya keduanya mempunyai pendekatan berbeda. ${ }^{48}$ Namun demikian, terlepas dari perdebatan seputar kedua term tersebut, ada sisi gradual yang mempertemukan keduanya. Bahwa baik term tata kelola maupun manajemen konflik, keduanya memiliki tujuan sama, yakni bagaimana menggiring konflik pada wilayah-wilayah positif dan produktif, sehingga segala jenis praktik kekerasan dapat ditekan.

Secara definitif, sebagaimana disinggung di muka, tata kelola konflik dapat dimaknai sebagai upaya mensterilkan wilayah konflik dari pertentangan dan perselisihan yang bias kekerasan, di mana upaya tersebut berpangkal pada proses resolusi melalui penggunaan alat-alat

47 Ibid., 248.

${ }^{48}$ Susan, Sosiologi Konflik, 125. 
kekuasaan dan wewenang. Jika mengacu pada sudut pandang pengertian ini, strategi tata kelola konflik dapat memuat tiga kata kunci dasar, yakni kekuasaan, wewenang, dan perdamaian sebagai lawan kekerasan. Pertanyaan pentingnya adalah, apa yang dimaksud dengan kekuasaan dan wewenang dalam konteks tata kelola konflik? Bagaimana memahami konsep wewenang dan kekuasaan dalam kegunaannya sebagai instrument tata kelola konflik? Baik itu konflik yang berjenis vertikal maupun konflik horizontal. Dua pertanyaan ini penting dijawab untuk memberi pemahaman komprehensif tentang arti peran dan fungsi kekuasaan dan wewenang dalam manajemen konflik.

Dalam pembacaan yang umum, konsep kekuasaan lazimnya dipahami sebagai kemampuan menularkan pengaruh terhadap orang lain meskipun yang demikian bertentangan dengan kemauan dan kepentungan orang bersangkutan. ${ }^{49}$ Dalam studi konflik kontemporer, kekuasaan seringkali dipadankan dengan pemikiran besar Max Weber. Menurutnya, kekuasaan mempunyai dimensi hierarki yang bukan saja terbentuk berdasarkan kelas dan status seseorang. Lebih dari itu, dirinya juga dibentuk oleh dimensi kultural berbentuk prestise dan karismatik diri. ${ }^{50}$ Karenanya, kekuasaan tidak semata diproduksi oleh kalangan birokrat berdasarkan unsur legitimasi dan otoritas formal, namun juga melekat dalam diri kelompok atau kalangan tertentu yang dikenal sangat determinen dalam mengambil dan menentukan keputusan, sekalipun sikap determinennya tersebut disandarkan pada unsur-unsur kultural, seperti halnya karismatik dan daya prestise diri. Tidak cukup di situ, Weber juga tidak sependapat dengan pandangan kelompok marxian, yang meyakini kekuasaan bersumber dari komoditas ekonomi dan alat-alat produksi. Weber kukuh pada pemikirannya, bahwa struktur hierarki kelas masyarakat tidak saja bertumpu pada dimensi ekonomi, namun juga pada status sosial dan daya karismatiknya. Berangkat dari kerangka berpikir ini, Weber kemudian merumuskan kekuasaan menjadi tiga bagian, yakni kekuasaan berasaskan legal formal, kekuasaan berasaskan tradisional, dan terakhir kekuasaan berasaskan karismatik diri. ${ }^{51}$

\footnotetext{
49 Thomas Santoso, "Kekuasaan dan Kekerasan", Jurnal Masyarakat, Kebudayaan dan Politik, Vo. 16, No. 4 (Oktober 2001), 89-102.

${ }^{50}$ Goodman dan Ritzer, Teori Sosiologi Dari Klasik, 46.

51 Mustafa Mansur, dkk, "Otoritas Dan Legitimasi Studi Tentang Kedudukan Pemimpin Tradisional Di Loloda Maluku-Utara (1808-1958)", Sosiobumaniora, Vol. 15, No. 1 (2013), 65.
} 
Masih dalam penjelasan Weber, kekuasaan legal formal adalah satu jenis kekuasaan yang diperoleh berdasarkan legitimasi dan sistem rasio. ${ }^{52}$ Tipe kekuasaan ini, menurut Weber, dapat ditemukan pada struktur birokrasi, yang dalam pandangannya dinilai sebagai wujud ideal kekuasaan legal formal. Pada umumnya, struktur kekuasaan legal formal berbentuk birokrasi dilandasi oleh alat-alat kekuasaan seperti perangkat hukum, aparat kepolisian, partai politik, dan lain sejenisnya. Jika dikaitkan dengan tata kelola konflik kontemporer, kekuasaan legal formal di sini dapat memainkan fungsi dan peran strategis dalam hal melakukan intervensi konflik. Intervensi konflik adalah upaya nyata bagaimana mereduksi konflik menjadi suatu yang produktif, menghasilkan keputusan yang dapat mewakili kepentingan bersama tanpa melibatkan unsur atau praktik kekerasan. Intervensi konflik melalui alat-alat kekuasaan legal formal dapat diberlakukan dalam segala jenis dan tipe konflik, baik konflik bertipe vertikal maupun konflik horizontal.

Lain halnya dengan kekuasaan legal formal yang mendasarkan pada struktur dan sistem rasional, kekuasaan berbasis tradisional lebih didasarkan kepada klaim kepemimpinan, kepercayaan, dan keyakinan. ${ }^{53}$ Pada kekuasaan ini, tidak didapati adanya struktur birokrasi sebagaimana kekuasaan formal, karena semua struktur kekuaaan lebih cenderung dijalankan dengan model sentralistik. Jika dicontohkan kekuasaan tradisional di sini ada dalam diri ketua adat, seperti yang berlaku di desa-desa yang memiliki tipologi tradisional atau terbelakang. Jika melandaskan pada pembacaan ini, kekuasaan berbasis tradisional sangat relevan digunakan untuk menyelesaikan permasalahan sosial yang ada pada tataran konflik horizontal atau massa. Dalam beberapa situasi, seperti halnya konflik di pedesaan dan daerah-daerah adat, tata kelola konflik melalui upaya intervensi lebih memungkinkan dilakukan jika menggunakan intervensi kekuasaan berbasis tradisional. Dalam konteks ini, keberadaan tokoh atau ketua adat dalam kapasitasnya sebagai pemimpin lokal, dapat memosisikan dirinya sebagai pihak ketiga yang dapat melerai pertentangan dan menekan potensi terjadinya tindak kekerasan.

52 Miriam Budiardjo, Aneka Pemikiran tentang Kuasa dan Wibawa Jakarta: Sinar Harapan, 1991), 15.

53 Musafir Pababbari, "Patronase Agama dalam Kehidupan Politik", Annual Conference on Islamic Studies (ACIS) Ke-10 (2010), 588. 
Jenis kekuasaan terakhir menurut Max Weber adalah kekuasaan berasaskan karismatik. Pada umumnya, jenis kekuasaan ini dibentuk oleh kepercayaan sekitar tentang adanya karisma dalam diri seorang, karenanya semakin besar rasa kagum dan kepercayaan kelompok masyarakat terhadap orang tertentu, maka akan semkian besar pula karisma dirinya. ${ }^{54}$ Begitupun seterusnya, semakin besar karisma diri, maka semakin luas pula dirinya menularkan pengaruh kepada masyarakat. Menurut Weber, ciri umum kekuasaan karismatik identik dengan kemampuan personal yang bersifat magis, supernatural, penguasaan ilmu kanuragan, dan sejenisnya. Sama dengan kekuasaan tradisional, kekuasaan karismatik tidak memiliki bangunan kekuasaan terstruktur dan rasional, tidak ada pembagian tugas dan fungsi yang didasarkan pada spefikasi dan kemampuan personal. Sistem kerja kekuasaan lebih bertumpu pada kehadiran figuritas dan ketokohan. Hal pembeda antara kekuasaan karismatik dan kekuasaan tradisional terletak pada pola pembentukannya. Bahwa, kekuasaan tradisional dapat diperoleh melalui jalur trah atau keturunan yang diwariskan oleh para pendahulunya. Karenanya, kekuasaan ini berlaku sebatas pada kelompok atau kalangan tertentu saja, misal tokoh adat, kiai dan sejenisnya. Sebaliknya, kekuasaan karismatik berlaku umum. Artinya, dapat diperoleh oleh individu atau kelompok mayarakat lintas kelas dan kalangan, meski pada kenyatannya berasal dari keluarga atau kelas sosial yang biasa saja. Berkenaan dengan manajemen konflik, kekuasaan berbasis karismatik memiliki fungsi dan pera relatif sama dengan kekuasaan tradisional, yakni sama-sama dapat diberlakukan sebagai alat intervensi konflik di kalangan massa. Terutama konflik sosial yang bergulir di tataran masyarakat tradisional. Hal yang perlu dipertegas di sini berkenaan dengan tata kalola atau manajemen konflik, bahwa tata kelola konflik, baik melalui intervensi kekuasaan legal formal, kekuasaan tradisional, dan kekuasaan karismatik, pada prinsipnya bukan ditujukan menghilangkan masalah, tapi bagaimana menelusuri akarnya. Mengelola sekian perbedaan antarkelompok berkepentingan menjadi kesepahaman yang dapat mewakili tujuan dan kepentingan semua kalangan tanpa terkecuali.

\section{Catatan Akhir}

Konflik sosial dalam kedudukannya sebagai bagian dari realitas kehidupan masyarakat memiliki pengertian bertemunya dua

${ }^{54}$ Goodman dan Ritzer, Teori Sosiologi, 142. 
kepentingan berbeda, di mana perbedaan kepentingan tersebut menimbulkan hubungan persinggungan dan perselisihan. Konflik sendiri dapat berkembang pada dua sisi berbeda, yakni sisi positif dan sisi negatif. Konflik berkembang ke arah postif manakala dapat dikelola dengan arif dan bijak. Konsep positif di sini mengisyaratkan atas terciptanya satu kesepahaman bersama yang dapat mengakomodir kepentingan lintas kelompok. Sebaliknya, konflik dapat berkembang ke arah negatif ketika pengelolannya tidak dapat menemui titik kesepahaman, sehingga perkembangannya mengarah pada perilaku pertentangan dan tindak kekerasan.

Konflik sosial dapat dikelompokkan berdasarkan jenis dan tipenya. Berdasarkan jenisnya, konflik sosial dapat dibagi menjadi dua bagian, yaitu konflik vertikal dan konflik horizontal. Konflik vertikal adalah konflik yang memiliki pola dari bawah ke atas, atau sebaliknya dari atas ke bawah. Persisnya, konflik vertikal adalah konflik yang melibatkan kaum elit dengan kalangan massa. Kelompok elit di sini berupa kaum birokrat, aparatur pemerintah, pemodal, bangsawan, atau tokoh lokal. Sedangkan konteks massa merujuk pada keberadaan massa atau rakyat biasa. Adapun konflik horizontal adalah konflik yang memiliki pola sejajar, konflik yang terjadi di kalangan massa, tanpa melibatkan pertentangan dua kelas sosial tertentu. Sedangkan berdasarkan tipenya, konflik sosial dapat berupa empat bentuk, yakni konflik tanpa kekerasan, konflik laten, konflik terbuka, dan konflik di permukaan.

Tata kelola atau manajemen konflik mengandung pengertian segala upaya menghindarkan konflik dari pertentangan dan perselisihan yang bias kekerasan, di mana upaya tersebut berpangkal pada proses resolusi melalui penggunaan alat kekuasaan dan wewenang. Tata kelola konflik mengisyaratkan pada adanya intervensi konflik. Intervensi konflik dijalankan oleh pihak berkonflik atau pihak ketiga yang memiliki kekuasaan atau sumber daya yang besar untuk menstabilkan konflik. Konteks kekuasaan dalam tata kelola konflik dapat berbentuk tiga jenis, yakni kekuasaan legal formal, kekuasaan tradisional, dan kekuasaan karismatik. Kekuasaan legal formal adalah kekuasaan yang berlandaskan pada perangkat legitimasi, seperti hukum, perundangan, dan sejaninya. Kekuasaan tradisional adalah kekuasaan yang berasaskan pada klaim keyakinan, kepercayaan, dan adat istiadat. Sedangkan kekuasaan karismatik adalah kekuasaan yang 
berlandaskan pada kemampuan personal yang bersifat magis, seperti supernatural dan lain sebagainya.

\section{Daftar Rujukan}

Adian, Donny Gahral. Percik Pemikiran Kontemporer. Yogyakarta: Jalasutra, 2002.

Azra, Azyumardi. Konflik Baru Antar Peradaban. Jakarta: RajaGrafindo, 2002.

BM, St. Aisyah. "Konflik Sosial Dalam Hubungan Antar Umat Beragama", Jurnal Dakwah Tabligh, Vol. 15, No. 2, Desember 2014.

Budiardjo, Miriam. Aneka Pemikiran tentang Kuasa dan Wibawa. Jakarta: Sinar Harapan, 1991.

Dahrendorf, Ralf. Konflik dan Konflik Dalam Masyarakat Industri; Sebuah Analisa Kritik Ralf Darbrendorf. Jakarta: Rajawali, 1986.

Edkins, Jenny dan Williams, Nick Vaughan. Teori-teori Kritis. Yogyakarta: Pustaka Pelajar, 2009.

Esposito, John L. Masa Depan Islam, terj. Eva Y. Nukman dan Edi Wahyu SM. Bandung: Mizan, 2010.

Fisher, dkk. Mengelola Konflik Keterampilan dan Strategi untuk Bertindak, terj. Kartikasari, dkk. SMK Jakarta: Grafika Desa Putra, 2001.

Fisher, Simon dkk. Mengelola Konflik: Keterampilan dan Strategi Untuk Bertindak, terj. S. N. Kartikasari, dkk. Jakarta: The British Counsil Indonesia, 2001.

Fitria, Vita. "Konflik Peradaban Samuel P. Huntington; Kebangkitan Islam yang Dirisaukan?”, Humanika, Vol. 9, No. 1, Maret 2009.

Hannan, Abd. "Fanatisme dan Stigma Sosial Pesantren Miftahul Ulum terhadap Kelompok Muhammadiyah di Pamekasan”. Tesis-Universitas Airlangga, 2016.

Hannan, Abd. Perempuan Madura, Gender, dan Pembangunan. Yogyakarta:

Pusat Kajian Sosiologi UTM bekerja sama dengan Penerbit Elmatera, 2016.

Haryanto, Sindung. Spectrum Pemikiran Sosial. Yogyakarta: Ar-Ruzz Media, 2011.

Huntington, Samuel P. Benturan Antarperadaban dan Masa Depan Politik Dunia, terj. M. Sadat Ismail. Yogyakarta: Qalam, 2002.

-----. The Clash of Civilization?. Summer: Foreign Affairs, 1993. 
Irwandi dan Endah R. Chotim, "Analisis Konflik Antara Masyarakat, Pemerintah dan Swasta; Studi Kasus di Dusun Sungai Samak, Desa Sungai Samak, Kecamatan Badau, Kabupaten Belitung”, JISPO, Vol. 7, No. 2, 2016.

Maliki, Zainuddin. Narasi Agung: Tiga Teori Sosial Hegemonik. Surabaya: LPAM, 2003.

Mansur, Mustafa dkk. "Otoritas dan Legitimasi: Studi Tentang Kedudukan Pemimpin Tradisional di Loloda Maluku-Utara (18081958)", Sosiohumaniora, Vol. 15, No. 1, 2013.

Pababbari, Musafir. "Patronase Agama dalam Kehidupan Politik", Annual Conference on Islamic Studies (ACIS) Ke-10, 2010.

Ramadhan, M. "Teologi Kemanusiaan Studi atas Pemikiran Ali Syariati”, TEOLOGLA, Vol. 22, No. 2, Juli 2011.

Ritzer, George dan Goodman, Douglass J. Teori Sosiologi Dari Klasik Sampai Postmodern, terj. Nurhadi. Bantul: Kreasi Wacana, 2010.

Ritzer, George. Sosiologi Ilmu Pengetabuan Berparadigma Ganda, terj. Alimandan. Jakarta: PT Raja Grafindo Persada, 2004.

Rosyidin, Mohamad. "Konflik Internasional Abad ke-21? Benturan Antarnegara Demokrasi dan Masa Depan Politik Dunia", Jurnal Ilmu Sosial dan Ilmu Politik, Vol. 18, No. 3, 2015.

Santoso, Listiyono dkk. Epistimologi Kiri. Yogyakarta: Ar-Ruzz Media, 2012.

Santoso, Thomas. "Kekuasaan dan Kekerasan", Jurnal Masyarakat, Kebudayaan dan Politik, Vo. 16, No. 4, Oktober 2001.

Sobur, Alex. "Membangun Dialog Antarperadaban", Mimbar: Jurnal Sosial dan Pembangunan, Vol. 18, No. 2, Juni 2002.

Susan, Novri. Sosiologi Konflik dan Isu-isu Konflik Kontemporer. Jakarta: Prenada Media Group, 2009.

Usman, Sunyoto. Sosiologi, Sejarah, dan Metodologi. Yogyakarta: CiRed, 2004. 